\title{
Supporting the Adoption of Technology Enhanced Learning by Academics at Universities
}

\author{
Ann Thanaraj ${ }^{1}$ and Steve Williams ${ }^{2}$
}

\begin{abstract}
This paper makes a number of recommendations to academic leaders and practicing academics on promoting the uptake of technology-enhanced learning (TEL) across their institutions and on their programmes. The approach throughout is to privilege the academic voice and to reflect the views of practicing academics and their students. The authors - the heads of an academic department and of a service department - describe their case study approach, primarily covering staff and students in two different universities. The results are analysed in the context of existing change and adoption models. The authors conclude that existing models are inappropriate and posit their own model for the adoption of TEL, described as 'Policy-led, large-scale, incremental adoption.' The impact of the study is assessed. The authors acknowledge that there is no single best practice for full adoption of TEL across a university. We contend that this analysis and these recommendations will equip academic leaders and curriculum designers to deliver the benefits of effective adoption of TEL across subject disciplines.
\end{abstract}

Key words: Technology enhanced learning, adoption theory, barriers and enablers, institutional factors

\footnotetext{
${ }^{1}$ Principal Lecturer in Law, University of Cumbria, Fusehill Street campus, Carlisle CA1 2HH, United Kingdom

${ }^{2}$ Director of University IT, Newcastle University, Claremont Tower, Claremont Road, Newcastle upon Tyne NE1 7RU, United Kingdom
} 
The aim of this study is to raise the profile of how universities can support academics in implementing their university strategy on Technology-Enhanced Learning (TEL), thereby contributing to the transformation of students' learning. Our study suggests that individual universities should undertake a contextual analysis of the factors that motivate and constrain academics in their own organisations to engage with technology in curriculum delivery and development. It encourages each university to explore how the barriers and motivators can be used to develop and implement TEL in the specific circumstances of the institution.

For the purposes of this study, TEL is defined by the authors as the use of learning technology to make learning more effective.

To underpin the research, the authors considered a range of change and adoption models. Since each was found wanting in the context of TEL adoption, this study offers an adoption model designed by the authors. Through the model, a set of recommendations and guidelines have been developed on how institutional leaders should develop and publicise a vision for what TEL can do for their own organisation. The study acknowledges that, in the majority of universities, TEL alone is rarely the answer to enhancing the quality of the learning experience in higher education. The authors support, in most cases, a blended approach to TEL in partnership with face-to-face classroom learning experiences. However, the focus of the study is the adoption of TEL by academics and the factors that enable or hinder such adoption.

The authors hope that institutional leaders and academics will use this study to enhance their own plans for effective use of TEL.

An opinion paper was published in November 2014 with an initial treatment of this material (Thanaraj and Williams 2014.) The current paper provides a comprehensive analysis of our model of adoption of TEL which underpinned the research, a detailed discussion of our findings, a full set of recommendations and an outline of the desired impact of the work.

\section{Rationale for the study}

Research argues that many universities are still struggling to engage a significant percentage of students and staff with TEL and real development beyond projects by innovators has so far been modest (Beetham, McGill, and Littlejohn 2009.) This is despite the fact that embedding TEL is a stated aspiration of many policy-makers and senior managers. It is telling that the conclusions of this seminal paper still apply six years on, despite very rapid technological changes in the interim. In over a decade, Oliver and Dempster (2003), Kelton (2007) and Gourlay, Hamilton, and Lea (2014) have concluded that there is no ready model that universities can utilize to embed the adoption of TEL.

Much of the focus of past research on the adoption of TEL has been into the development of technologies or top-down policy aspirations (Salmon, 2005) and there is little on the human dimensions which inhibit or motivate academics to adopt TEL The authors believe that the behaviour of academics influences the learning of students, and it is therefore academics who must adopt TEL-friendly behaviours if the learning is to be enhanced This led to the authors embarking on this study. It will be difficult to implement TEL without the cooperation and support of the large majority of lecturers, as the degree of interaction between lecturers and students is still predominant in TEL environments (Warburton, 2009; Kirriemuir 2010a; Kelton, 2007, 2008). Academic staff will change their methods of teaching and learning and programme outcomes if they gain a deep understanding of what the 
impact will be in terms of quality and any resultant benefits (Salmon 2005; Sharpe 2006; Gourlay, Hamilton, and Lea, 2014).

This research will propose that Universities require a fully articulated TEL strategy that aims to have a sustainable effect across the university, with the aim of transforming teaching, offering accessibility to education to a wider student population, internationalising the existing curriculum and developing holistic, well-rounded graduates with global and cultural knowledge. The TEL strategy can stand alone, alongside the Learning and Teaching strategy, or can be woven into it.

The research therefore proposes that, to develop strategies and vision for TEL that are successful, university leaders must give the opportunity to debate, discuss and develop action plans with policy makers on the reasons why their particular university is adopting TEL approaches, the educational experience that blended learning offers their students, the impact it has to subject areas, the change in expectations for staff and students and the process by which TEL adoption will be implemented. Furthermore, it must be recognised that adopting technology is 'a complex, barrier-ridden and time-consuming process...' (Jacobsen, 2000, p. 26).

Literature on the barriers and enablers to the adoption of TEL has ranged from surveys to questionnaires. Research has found that '....rewards such as a feeling of accomplishment and personal satisfaction', are key enablers (Larson, 2005, p. 104). Factors such as '...extra pay, recognition and awards, and royalties on copyright material', did not motivate academics to adopt TEL (Parker, 2003). Key factors leading to resistance in engaging or adopting TEL, including the lack of time (Berge et al. 2002; Maguire 2005; Lahaie 2007; Major 2010), increased workload (Maguire 2005; Lahaie 2007; Major 2010); lack of compensation (Berge et al. 2002), and lack of IT support (Maguire 2005) are well documented. Recent University and College Information Systems Association (UCISA) studies $(2010,2012)$ showed that the lack of academic staff knowledge was the top barrier for academics. An academic's experience and their expertise with the technology were found to be key indicators for successful adoption of TEL (Lane \& Lyle, 2010.) There was a clear and real necessity for academics to understand how a particular technology operated and its stability and reliability towards delivering a specific learning objective were shown to be the top enablers to the adoption of TEL (Sharpe \& Beetham, 2010).

Most research in this area investigates barriers, whilst enabling factors are seldom mentioned or examined. There also does not appear to be much research which privileges the academic's voice and lived experience. In spite of the work in this area to date, further study is needed to test several aspects around the question of the adoption of TEL. This will aid us in exploring how the motivators can be used as part of driving TEL forward in an institution, whilst addressing the restraining factors that could be in the way. This study advocates that the success of implementing TEL initiatives lies with academics as individuals and with academic leaders in establishing the right conditions.

\section{Research question}

How can universities support academics in implementing their university strategy on TEL so that it improves students' learning?

\section{Sub-questions}


1. What are the needs, concerns and motivating factors facing academics in the adoption of TEL?

2. How can universities balance the need for a coherent strategy on TEL with academic freedom and integrity towards different subject disciplines?

3. What is the most appropriate adoption or change theory that universities can utilize in aiding understanding of the data gathered in this study?

4. What stance should a University's IT Service take in its support for TEL?

5. How can institutional leaders support the adoption of TEL and make the benefits clear to academics?

\section{Literature review on models for the adoption of TEL}

The purpose of this study is to bring about sustained and transformative change to the ways in which universities encourage academics to adopt TEL. This in turn will meet the changing landscape of higher education in the UK and allow UK universities to stand as successful competitors in the wider global education sector.

It is appropriate to develop a model to help consider this. The apocryphal reasons for the reticence to adopt TEL are well known - time, technology, established practice, institutional inertia and so on. A model will help practitioners to formulate and test their ideas and thereby to reshape their practice.

To build understanding, the authors first considered whether a change or an adoption model was appropriate for the study. The authors developed an illustration of why it is appropriate to consider an adoption framework. For academic staff to adopt TEL, they need to alter their ways of working, but not the fundamental purpose or content of that work. Making optimum use of TEL is more than simply using what we have - it typically requires academics to use a range of different tools, some familiar and some initially unfamiliar. The core purpose, though, remains the effective learning of their cohort(s) of students. The authors used the following model:

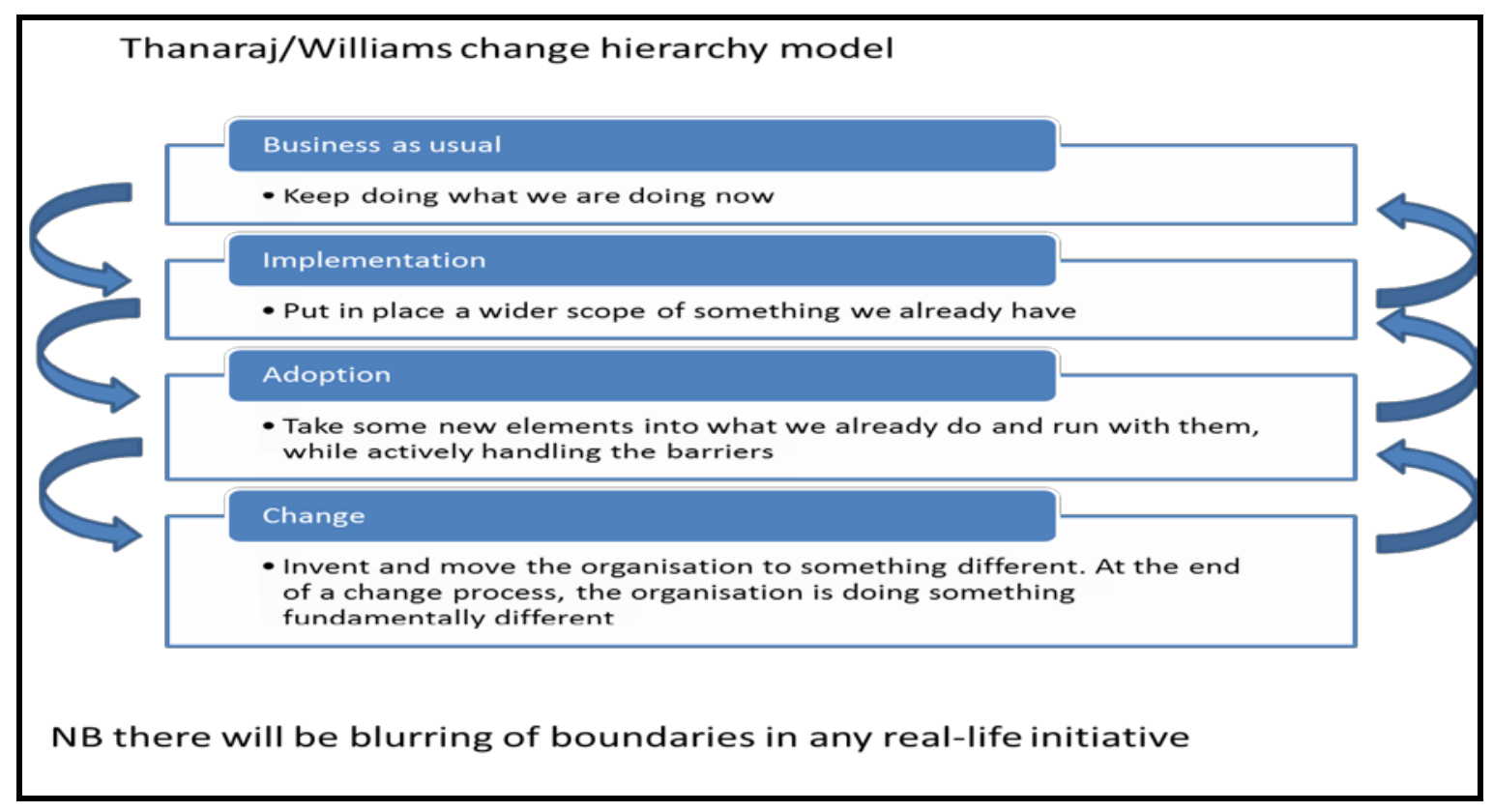

Journal of Teaching and Learning with Technology, Vol. 5, No. 1, July 2016 jotlt.indiana.edu 


\section{Figure 1: Change hierachy model, Thanaraj \& Williams (2015)}

The authors then reviewed a number of the well-known adoption models. Adoption usually starts with the recognition that a need exists and moves to searching for solutions. Then comes the initial decision to attempt the adoption of a solution, and finally the actual decision to proceed with the implementation of the solution (Damanpour and Schneider 2006; Gallivan 2001; Mendel et al. 2008). The authors argue that to support the adoption of innovation, the process needs to be made in a systematic and planned way, as the method of use will determine how successfully an initiative can be implemented and sustained.

In order to assess the most suitable model for bringing about adoption of TEL within universities, this study reviewed the different types of adoption frameworks by drawing out the key characteristics which are likely to increase adoption of innovation. The authors began by reviewing ten frameworks which address the adoption process. Two models which stood out were Rogers's Innovation diffusion theory (Rogers, $5^{\text {th }}$ ed., 2003) and the Technology Adoption Model version 3 (Davies, 1985; Venkatesh and Bala, 2008).

There have been many studies within the education setting (Medlin, 2001; Dooley and Murphrey 2000, Graham 2006, Wilson \& Stacey, 2003) which have used Roger's diffusion theory to examine the uptake of educational technology. Drawing upon the practicalities of the theory, Jacobsen (2000) makes the point that 'If campus wide integration plans are developed on the assumption that everyone will naturally use computers as readily and as easily as the early adopter, then they are bound to fail' (p. 25). Instead, it is essential to recognise that '.. the adoption of information technology for teaching and learning is a complex, barrier-ridden and time-consuming process will help institutions understand that expectations for campus-wise technology integration will not happen overnight, and must allow for a cyclical and iterative implementation and evaluation process' (Jacobsen 2000, p. 26).

Venkatesh and Bala's (2008) Technology Adoption Model (version 3) provides a framework to explain the factors which influence the adoption of technology such as user participation in the pre-implementation and implementation stages, aligning the invention with job requirements, training, peer and organizational support. These are valuable factors, however, studies such as Chutter (2009) have claimed that there are some doubts about its theoretical robustness and practical effectiveness.

In addition to adoption frameworks, the authors also frameworks which addressed the implementation, dissemination and sustainability of adoption. Most adoption models focused on the adoption of technology itself rather than the adoption of new or enhanced ways of delivery through technology, which is necessary for universities to model their strategies on. The findings of this analysis are presented below. In some cases, the authors have appended their views on how the factors reviewed impact on universities adopting TEL practices.

In order for technological practices to be adopted successfully, much of the research points to the successful and lasting impact which regulators, government policies and legislations have (Aarons et al. 2011; Berta et al. 2005; Feldstein and Glasgow 2008; Mitchell et al. 2010). Some kind of mandate is regarded as essential. Within universities, educational policies and funding changes, and the progressive change of the manner in which we teach our students are key factors for all academic leaders. The political and cultural climate of higher education (Glasgow et al. 2003), alongside successful collaborative activities with innovation developers, education consultants and students, are steps to ensure that TEL is 
adopted for the right reasons and in a manner which is appropriate to the university concerned.

Any message of adopting something different or changing practices will require a clear need for motivation, urgency and readiness for change from all stakeholders concerned (Solomons and Spross 2011). In order to bring about successful adoption, organisations need to undertake an assessment of attitudes, barriers and facilitators towards change (Aarons et al. 2011; Gallivan 2001; Mendel et al. 2008; Solomons and Spross 2011), and to build in methods for rewarding adoption and innovation (Glasgow et al. 2003, Aarons et al. 2011). Feedback on the adoption process and consultation from those required to engage are useful in increasing adoption. Taking into consideration individual characteristics, such as skills and experience of staff, innovativeness, tolerance of ambiguity and propensity towards risk taking, is associated with increased adoption (Solomons and Spross 2011). Academics' lack of awareness and familiarity with a particular practice, the lack of time, autonomy, and ability to access research are also factors that inhibit the successful adoption of technology. The authors argue that these are key factors that must be considered carefully and woven into the adoption model for successful, risk-assessed and sustainable change.

New approaches will only be successfully implemented if they are led through effective communication with clear and focused messages, backed up by evidence of successful outcomes, including a clear advantage in effectiveness over the preceding idea, product, or program (Graham and Logan 2004). It is possible for adoption to be successful and sustainable where strategies are developed to suit organizational needs, compatible with practice norms, with evidence of practice efficacy (Feldstein and Glasgow 2008; Oldenburg and Glanz 2008;) Furthermore, organisations will need to be shown to invest in their strategies (Godin et al. 2008, Graham and Logan 2004, Mendel et al. 2008, Simpson 2002) with structures in place to support adoption through training and communication and consultation with stakeholders (Berta et al.2005; Solomons and Spross 2011).

Within this literature review, the authors have offered the key themes, at a generic level, to successful adoption of technology. However, the review suggests that none of the prevalent adoption models accurately reflects the needs of institutions in supporting the adoption of TEL. The authors believe that a new adoption model, tailored for TEL in universities, is needed. Educational organisations are commonly typified as professional bureaucracies employing numerous types of professionals. They often exhibit a dual hierarchical structure with considerable autonomy. Individual academics typically exercise substantial discretion. As a consequence, educational organisations continue to be distinctive in their organisational characteristics; decision-making tends to be more decentralised and more localised to specialised subject areas than in the typical organisation.

The authors believe that it is more appropriate to consider a model focused on the factors which university leaders should consider to bring about enhanced ways of teaching with technology. We have used some of the thinking in many of the models in the literature and attempted to craft something which is simple, appropriate for use in higher education, and builds on previous thinking in the adoption of innovation in other sectors.

\section{Methodology and data collection}

There were three parts to the study:

1. Context: Contextual analysis to determine academics' needs, concerns and motivations about the adoption of TEL 
2. Case study: Two Higher Education Institutions examining their TEL practices and implementation strategies, using a combination of focus groups and interviews

3. Outcome: Recommendations and guidelines for sustainable and transformative implementation of TEL

The study featured two institutions in the North of England: Newcastle University, a research intensive institution, and University of Cumbria, a newer, teaching-led institution. These universities were chosen because of their diverse nature in their institutional objectives and missions. This provided rich perspectives on the similarities and differences in the factors that motivate or hinder the adoption of TEL. The TEL strategies for both universities are at different stages. Newcastle University has institutional wide TEL activities (such as wideranging lecture capture and ePortfolio projects) which are adopted by the majority of academic units. University of Cumbria has a variety of TEL initiatives developed through individual pockets of excellence; however these need to be shared across departments for institutional adoption and impact.

A case study methodology was used in this study. Case studies are especially useful when looking for patterns of behaviours concerned with 'how' and 'why' (Saunders et al., 2000) the use of TEL in teaching and curriculum design may, or may not be taken up by academics. Furthermore, the exploratory nature of the research questions, the study of participants' behaviour and the need to study the contextual situations of the institutions lend themselves to a case study approach (Baxter \& Jack, 2008). The case study approach offers the opportunity to compare and contrast real life experiences (Yin, 1994; Stake, 2005) between academics from the same institution and across both institutions, allowing the researcher to capture the variation in experiences. This has assisted the authors in drawing out a more compelling and robust set of conclusions and recommendations from the study (Yin, 2009.)

One of the greatest strength of case studies is the multiple sources of data collection (Yin 2003). Stiles (2004) has argued persuasively that: 'understanding where you are starting from is as important as understanding where you want to get to. Expanding the use of eLearning in an institution requires a clear and honest analysis of the organisation in terms of strengths and weaknesses viewed against its strategic goals'. (p.14). Friesen, Gourlay, and Oliver (2014) argue for the importance of developing an empirically grounded set of findings in order to take forward any technology based learning initiatives. This approach allowed the authors to expose the more personal, cultural and organisational reasons why individuals elect to take up or avoid online teaching, driven by the research questions of the study.

To underpin the case study, six focus groups with participation of just under sixty individuals, and a number of interviews were organised across both institutions. Although 'it is nearly impossible to replicate the original conditions under which the data were collected' (Strauss and Corbin, 1998, p. 266), the authors considered carefully the make-up of the focus groups in both institutions alongside timing during the academic calendar and method of participant selection.

The focus groups offered a free space for academics and professional service staff to discuss the following statements, taking fifteen minutes for each:

- I would like to support students' learning more by using online tools, but...

- I see benefits in supporting students online, because... 
- There are concrete actions that institutions can take to help staff become more effective in their teaching by using online tools.

The first and second questions are deliberately contradictory - the authors wanted the audience to adopt a negative and a positive outlook, respectively, influenced by de Bono's yellow and black hats (De Bono, 2004).

Each focus group lasted approximately one hour. The purpose was to examine how TEL is being adopted, embedded and used by those participating in the focus group. This will provide scope for university leaders and policy makers to assess where TEL is at the organisation and identify opportunities for progress in their own organisation. It is hoped that it will also assist in selecting key individuals who would be well suited to lead change within their own departments and academic subject groups.

Running the focus groups with a self-selecting audience of those who replied to the invitations opens up risks of possible bias. Indeed, these risks apply more widely to the whole of the case study approach and also apply to studies such as this where sample sizes are relatively small (two universities; some sixty people.) Other criticisms, such as the potential for sloppy procedures, poor analysis and lack of rigour, practical challenges with the quantity of data collected and the management of that data, also apply (Yin, 2009). To mitigate these risks, the authors consulted a professional statistician, who reassured them that the validity of the conclusions would not be compromised as long as the questions about positive and negative opinions were asked openly. No attempt was made to produce a representative sample, but following the principles of purposive sampling, (Bryman 2004) a cross section was sought, especially across a range of subject disciplines in both institutions.

To further enrich the data, the analysis was expanded by six semi-structured interviews with institutional representatives to provide the richest variety of evidence and insight into the 'human' motivations on the adoption of TEL. The guided, semi-structured nature of the interviews allowed the authors to ensure consistency in the topics covered (Cohen et al., 2007) while allowing for individual differences, and allowing the interviewer to bring out the experiences and viewpoints of each participant, raising issues that are important to individuals (Ritchie \& Lewis, 2003) The interviews lasted around 40 minutes each.

Further, a content analysis method was employed to the interview data and to carry out analysis on strategy documents in learning and teaching, and in TEL. This method of analysing data offers the ability to analyse the same data consistently over two iterations (Babbie, 2010). Content analysis reveals differences in communication content by identifying the intentions, focus and communication trends through attitudinal and behavioural responses to communications (Nuendorf, 2002). It is an unobtrusive means of analysing social interactions and provides insight into human thought and language use (Lasswell, 1948).

The analysis of the case study results utilised all the evidence from the focus groups, interviews and documentary evidences. The authors examined the factors that influence academics' decisions to adopt and integrate learning technology, the pedagogical motivation or demotivation behind their decision and, drawing upon the specific structures of the two universities, the motivational and cultural values in the different academic communities.

The results of this study will focus on the needs, concerns and motivators to the adoption of TEL, assessed through the lens of personal, cultural and organisational factors in the two institutions. The authors believe that the findings may be of value to policymakers in other universities in considering their own positions, by understanding whether they can see any 
similarities between the universities under study and their own (Mays and Pope 2000; Onwuegbuzie and Leech 2005).

Validity of the study has been established by showing the link between the research questions and the data collection questions and the possibility of generalizability of the findings (Eisenhardt, 1989). Reliability of the study has been established by demonstrating and explaining how the same data collection process was used in both universities, across all focus groups and interviews. The process was documented in detail and records kept to show appropriate links (Saunders, 2000; Eisenhardt, 1989.) Anonymity and confidentially were guaranteed and participants were offered the chance to withdraw from the study before, during and up to two weeks after their participation. In order to assist with reviewing the data at a later stage, permission was sought from participants to take written notes during the focus groups and interviews.

\section{Philosophical and epistemological stance}

This study was conducted in the belief that knowledge is built by actively interpreting or constructing meaning through experiences as opposed to being discovered (Jonassen, 1991; Guba \& Lincoln, 1999; Richardson, 2004). The intention was to explore the perceptions of academics, to discover the extent to which different experiential and practical interpretations (Lincoln \& Guba, 2000) of cultural, pedagogical and institutional factors may influence the adoption of TEL. A social constructivist stance was utilized in the collection, analysis, and interpretation of data for this study, to create, explore considerations, and develop an awareness of differing experiences and opinions (Fischer, 2003.)

\section{Findings from the study}

The authors captured all of the focus group and interview input about enablers, barriers and institutional measures and, using content analysis, summarised the data into the following findings:

\section{Table 1: Findings from contextual analysis}


Journal of Teaching and Learning with Technology, Vol. 5, No. 1, July 2016, pp. 59-86.

\begin{tabular}{|c|c|c|}
\hline & Enablers & \\
\hline Both universities & Only at Newcastle University & $\begin{array}{c}\text { Only at University of } \\
\text { Cumbria }\end{array}$ \\
\hline \multirow[t]{2}{*}{$\begin{array}{l}\text { Student experience } \\
\text { Identity and belonging } \\
\text { Personalised learning } \\
\text { Flexibility } \\
\text { Creativity } \\
\text { Access to education through widening } \\
\text { participation and diversity }\end{array}$} & $\begin{array}{l}\text { Motivated by the better retention of } \\
\text { students } \\
\text { Enhanced learning } \\
\text { International / cross faculty / cross } \\
\text { discipline opportunities } \\
\text { Employability } \\
\text { Staff development of skills } \\
\text { TEL as a priority for the university, } \\
\text { enhancing the university’s reputations } \\
\text { Staff recognition } \\
\text { Scalability, reliability and innovation } \\
\text { in the software }\end{array}$ & $\begin{array}{l}\text { Staff gain better } \\
\text { communication skills }\end{array}$ \\
\hline & Barriers & \\
\hline Both universities & Only at Newcastle University & $\begin{array}{c}\text { Only at University of } \\
\text { Cumbria }\end{array}$ \\
\hline \multirow[t]{2}{*}{$\begin{array}{l}\text { Sufficiency of digital literacy/fluency skills } \\
\text { Lack of concrete pedagogic evidence in } \\
\text { existing literature } \\
\text { The extent of career recognition and } \\
\text { progression } \\
\text { Impact on time, resource and staff workload } \\
\text { Lack of opportunity to communicate and share } \\
\text { best practice } \\
\text { Not knowing how it impacts student } \\
\text { experience of learning } \\
\text { Fear and reticence on the part of staff } \\
\text { Lack of sign posting of support and tools } \\
\text { Believing that just because it is E, it's not } \\
\text { better }\end{array}$} & $\begin{array}{l}\text { Staff support with the tools } \\
\text { Social diversity, widening } \\
\text { participation } \\
\text { Legal issues (copyright, IP) }\end{array}$ & $\begin{array}{l}\text { Developing multiple } \\
\text { online personalities } \\
\text { Design of online study } \\
\text { spaces } \\
\text { Staff disenfranchised } \\
\text { Assumption that } \\
\text { students are confident } \\
\text { with the tools } \\
\text { Student support with } \\
\text { the tools }\end{array}$ \\
\hline & Institutional Measures & \\
\hline Both universities & Only at Newcastle University & $\begin{array}{c}\text { Only at University of } \\
\text { Cumbria }\end{array}$ \\
\hline $\begin{array}{l}\text { Embed TEL into Learning, Teaching and } \\
\text { Assessment strategy, with QAA process } \\
\text { Reflect TEL involvement in staff workload } \\
\text { Localise use of TEL in Schools / Departments / } \\
\text { Subjects (practice) } \\
\text { Recognise research on teaching as a scholarly } \\
\text { activity } \\
\text { Make pedagogy fit the subject discipline } \\
\text { Invest in software, people and training }\end{array}$ & $\begin{array}{l}\text { Develop a long-term TEL plan } \\
\text { (sustainability AND transforming } \\
\text { learning) } \\
\text { Staff digital literacy plan. } \\
\text { Share best practice. } \\
\text { Develop hybrid managers } \\
\text { Be risk-aware rather than risk-averse } \\
\text { in new developments } \\
\text { Reward, recognition, incentive in TEL } \\
\text { Put students at the heart of education } \\
\text { Empower staff }\end{array}$ & $\begin{array}{l}\text { Managing hardware } \\
\text { and software well - } \\
\text { don't change too much } \\
\text { at once } \\
\text { Use suitable, } \\
\text { meaningful names for } \\
\text { TEL projects }\end{array}$ \\
\hline
\end{tabular}


Journal of Teaching and Learning with Technology, Vol. 5, No. 1, July 2016, pp. 59-86.

doi: 10.14434/jotlt.v5n1.18985

\section{Analysis of study}

This study proposes that, in order to deliver institution-wide change, consideration of the needs, concerns and motivating factors of academics in adopting TEL in curriculum and pedagogy must be addressed. The authors asked 'How can universities support academics in implementing their university strategy on TEL so that it improves students' learning?' The findings set out above make it clear that actions can be taken both at institutional and individual level which will benefit students.

The starting point is to embed TEL into the Learning and Teaching strategy. This can be achieved either by having a separate TEL strategy or by having a TEL section in the overall Learning and Teaching Strategy.

Recognising TEL involvement in staff workload modelling is essential. Developing high-quality and effective online material is a time-consuming task. An academic with a $110 \%$ teaching and research load is unlikely to be able to invest sufficient time in developing high-quality TEL material.

Further, universities should recognise research on teaching as a scholarly activity, welcoming publications in this domain both from their education department and elsewhere.

\section{Sub-questions}

1. What are the needs, concerns and motivating factors facing academics in the adoption of TEL?

Three headings cover these factors - Time, Skills, and 'What's in it for me?' Universities need to designate TEL as a priority for the institution as a whole, as an activity that enhances their reputation. Staff need allocation of the time to develop the appropriate skills and then to use those skills to produce high-quality material. This activity needs to be recognised as a credible, essential and valued element of an academic's work.

2. How can universities balance the need for a coherent strategy on TEL with academic freedom and integrity towards different subject disciplines?

Practicing academics were particularly insistent, in both Universities, that use of TEL in Schools / Departments should be localised, reflecting pedagogical differences between academic subjects, and feeding different requirements into - potentially - different IT systems. However, it was also well understood that there are cost and efficiency advantages in standardising on a small number of software platforms.

Some differences were apparent between the two universities. It's likely that the cultural, pedagogical and institutional perspectives may lead to a different position on TEL. Factors which could lead to differing perspectives include the level of research-intensity in the university, the reward and promotion criteria and the availability and responsiveness of high-quality IT systems. Differences in the university ethos, values and heritage have a role to play. When applying these questions to other universities, it seems advisable to consider these differences.

3. What is the most appropriate adoption or change theory that universities can utilize in aiding understanding of the data gathered in this study?

The authors considered a range of theories, covered earlier in the paper. Adoption models offer several mechanisms for successful adoption of TEL practices in universities. 
Leadership, fit with norms and values, and attitudes/motivation toward innovation are each mentioned in at least half of the theories and across organization, individual, and client contexts. Characteristics of adoption, however, are likely to have varying salience depending on the type of practice to be adopted and the type of organisation seeking such adoption. The literature to date provides thorough information on external, organizational, staff, and innovation characteristics. However, to apply this to each university, with its individual context, it is necessary to observe each of these characteristics and their fit from each organization's perspective. University leaders, policy makers and academic leaders need the scope to assess the level of TEL utilization and identify opportunities for progress in their own organisation.

Reflecting the fact that none of the models appears to fit the circumstances in individual universities, the authors developed an adoption model which universities could consider for their own TEL adoption. This is covered in the recommendations section below.

4. What stance should a University’s IT Service take in its support for TEL?

This is tricky. IT consultants Gartner talk of 'bimodal IT' - some parts of an IT department need to focus on robust, reliable services, while others concentrate on innovation and creativity. A payroll system, or an ambulance control system, needs to be $100 \%$ reliable, whereas the development of a mobile app needs to be fast-moving and creative (Gartner 2013).

TEL spans both. For example, a Virtual Learning Environment is typically used as the main channel for accessing learning materials and submitting work - so it needs to be very reliable indeed. However, it also needs to be flexible, allowing for different pedagogical approaches. IT teams in Universities need to concentrate on the innovative elements early in projects, and hand over carefully to the robust running of live services.

In any case, managing hardware and software well is essential. Changing too much at once can be extremely inconvenient for people - 'I've just got used to using version 10 and you're now replacing it with version 11.'

There are understandable pressures on cost and efficiency in all universities. These must be balanced with the need to support different pedagogies in different subjects. One extreme is to support one standard system only and to mandate its use. The other extreme is to support whatever each academic wants. This trade-off depends on the culture of the organisation and the similarities and differences between the different academic programmes offered.

Some arguments are based on real substance. As an example, some VLEs are weak at handling symbols in mathematics - if the institution teaches a number of online maths modules, then that may be a valid reason to use a different platform for these modules, even if this adds both complexity and cost. Other determinants might include the culture of the University. In teaching-focused post-92 universities, academics may be more prepared to tolerate the institutional solution, accepting the lower cost and - perhaps - more limited functionality. In research-intensives, the culture is more towards tailoring the service towards individual preferences. There's no right answer - it is for each university to address the issues openly and come to a view.

Co-development of technology solutions with partner organisations, whether fellow HEIs or commercial companies, adds a further set of complexities. IT services need to be involved from the outset in all such discussions, to ensure that IT platforms work effectively, integrate with other systems, and are sustainable. 
5. How can institutional leaders support the adoption of TEL and make the benefits clear to academics?

As so often, a long view is the starting point. This allows for universities to assess whether the new approaches to teaching and learning have been transformational and produced improved outputs. Further, it allows organisations to ensure that teaching approaches are sustainable.

Recognising the amount of work involved in effective TEL is the next priority. Then, institutions should support appropriate levels of investment in software, people and training and in establishing TEL-supported programmes. During our research, some academics called this a 'staff digital literacy plan.' A further aspect of developing staff is the idea of 'hybrid managers' - individuals who may have either academic or service delivery backgrounds, who understand both the pedagogy and the technology. To develop successful TEL programmes, universities need to reward, recognise and incentivise staff - principally academics, but also colleagues in service functions - for creating developments in TEL.

A positive, open attitude to risk is important - summarised as 'risk-aware, not riskaverse.'

Alongside these very practical measures, there are psychological imperatives too. Using meaningful, attractive names for projects makes them real to our customers - students and staff. For example, Newcastle's lecture capture programme is branded 'ReCap.' Having this name meant that the underlying software was able to be changed from one supplier to another without disruption to students’ learning.

\section{Conclusions}

The authors noted above that the existing adoption theories had some value when applied to TEL adoption at universities, but were unable to tell the whole story. This study agrees with the observation made by Jacobsen (2000) that '... the adoption of information technology for teaching and learning is complex, barrier-ridden and time-consuming... campus-wide technology integration will not happen overnight, and must allow for a cyclical and iterative implementation and evaluation process' (p. 26).

The findings from the study, and the authors' analysis, indicated that there are common principles in TEL adoption in universities, but also marked differences. Therefore there is no single optimal way for each university to proceed. We recommend below a number of steps, in line with an overall adoption model, which any university could take.

\section{Recommendations}

In 'Rethinking Pedagogy for the Digital Age', Beetham and Sharpe (2013), explored the challenges involved in implementing TEL in universities, concluding that the focus to successful TEL initiatives is in the human and organisational aspects of teaching and learning, rather than placing emphasis on the technology itself (p.56). Our study is in agreement with their findings. The goal, of course, is successful and sustained use of technology to enhance the learning, teaching and assessment experience across all programmes of delivery. Based on the findings of the study, the authors suggest that it is essential to look beyond the technology itself and instead focus on the pedagogical, cultural 
and social contexts of higher education in order to achieve successful and sustainable TEL adoption at universities.

The authors propose the following model for the adoption of TEL:

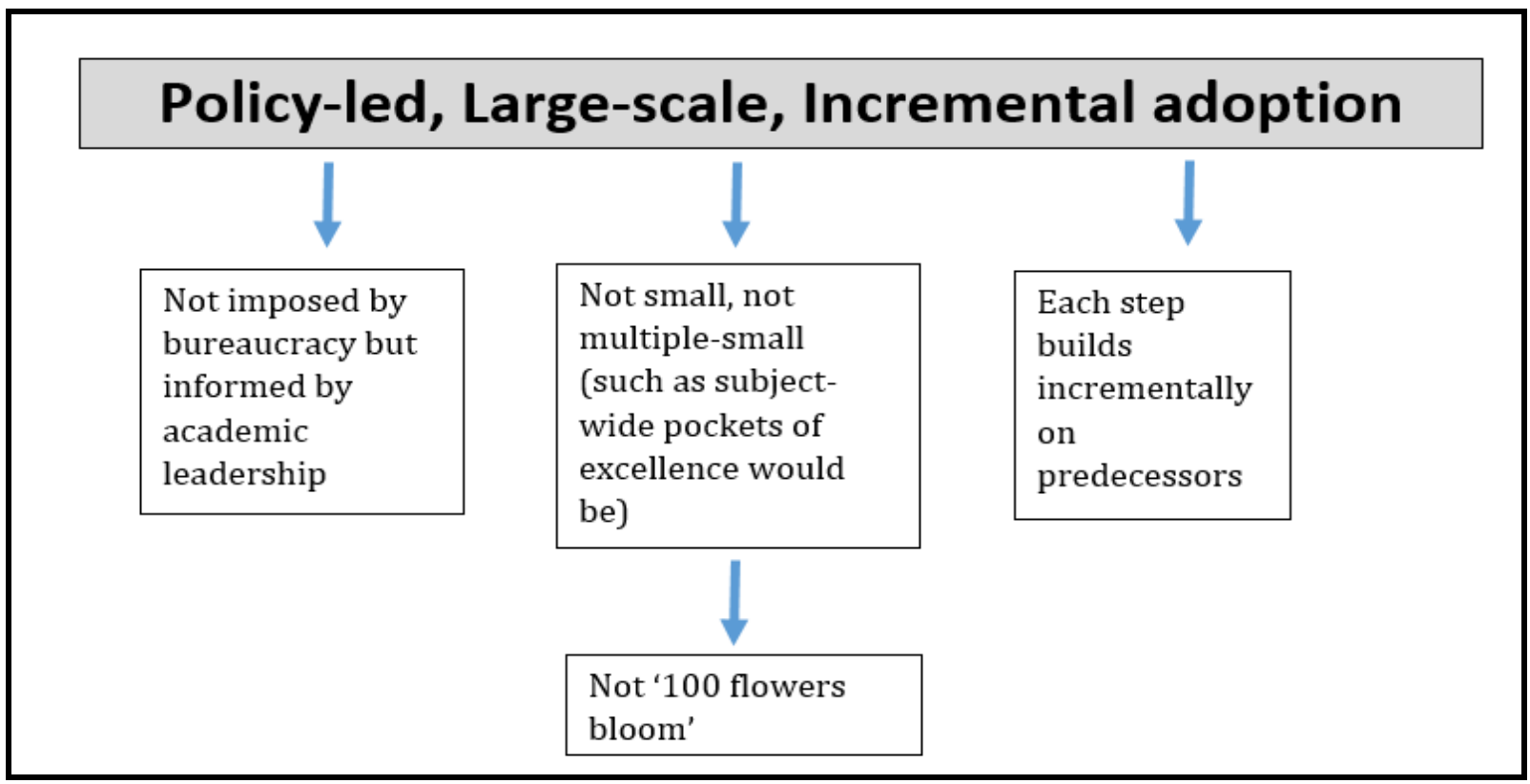

Figure 2: TEL adoption model, Thanaraj \& Williams (2016)

Reflecting this adoption model, the authors now recommend the following actions to universities in order to bring about sustainable and transformative adoption of effective TEL. In doing so, the recommendations address the barriers to adoption which we outlined in the Findings section.

Policy-led:

1. For institutions designing strategies or policy in learning and teaching and the manner in which this is delivered, there is a real need to facilitate a two-way communication. Room for questioning is essential to build commitment and trust. Universities should design strategies that target all levels of the university hierarchy, creating opportunities for every individual to contribute to the initiatives. Academic champions and policy designers should promote the new vision to all members of staff, explaining the rationale for the change and the potential transformation that could take place.

2. Change the culture of academic practice and recognition: Academics face complex pedagogical, technological, institutional and cultural challenges in the delivery of their programmes and in the adoption of TEL. They must be able to ask policy questions, debate issues, and articulate a defensible rationale on the adoption of TEL approaches, the challenge TEL presents to traditional assumptions and practices and how TEL may change expectations for students and themselves. Our findings indicated that the resistance to the uptake of TEL has been largely due to the lack of institutional support, such as inadequate time set aside for developing and delivering online teaching, recognition and promotion. Fair allocations in workload models are essential. There is 
unequivocal support in the literature for distance teaching taking more time to set up and facilitate than traditional teaching (such as Laurillard (2007) and Mancuso (2009)). There is a need for cultural change and a shift in the role of academics, their identity and methods of working, in order to ensure that facilitation and teaching online can be delivered satisfactorily.

3. Organisations should put in place a combined approach to TEL development. This approach should allow for mixing top-down and bottom-up strategy and activities. Senior management, practicing academics and members of service departments should interact and inform one another in order to integrate TEL more systematically and therefore bring about improvement in teaching and learning.

4. Universities should value both academic and technical support for TEL. Academics should be recognised as subject matter experts and content creators. Dedicated resources for technical support of TEL (such as IT and interaction design experts) need to be part of an integrated approach to programme development.

5. Use Meaningful names for TEL projects. Newcastle's lecture capture project is known as 'ReCap' - this has become a useful and popular brand with students and staff and has helped with the adoption of the service.

\section{Large scale:}

1. The strategies to achieve the vision should be offered as small and easy to achieve TEL projects, on a large scale basis across the university. As TEL moves beyond early adopters, universities should gently move towards a consistent set of technologies. When a university offers two or three TEL study programmes, then the technology platforms can be developed experimentally. Indeed, trying out different technologies and approaches is sensible. But as universities widen TEL adoption, they need to coalesce around a single set of standards, or at least a small number of options. It becomes unsupportable, both on technology and cost grounds, to do anything else. This needs to be handled sensitively, as academics and technical staff may need to redevelop early work in order to support the emerging standards.

2. In order to bring about sustained changes in practice, universities must address the myths of using technology in education. This requires concerted, university-wide attention. Some of these myths and barriers which arose from our findings included:

a. "With TEL, there is no role for tutors." In fact, the role of the tutor changes from teaching to facilitating and collaborating. The authors have argued, in line with other established literature that the best learning involves a combination of classroom and online support, therefore still requiring a tutor's input to teach.

b. "Tutors must be really skilled in IT." To make good use of educational technology available at the university, motivation, combined with a good understanding of digital pedagogy and basic IT literacy is all that is necessary.

c. "I'll be constantly writing backwards and forwards with my students." There are very good strategies for efficiently dealing with the volume of communications.; these include stating times when the academic will be available and agreeing response times for communication.

d. "Some subjects just cannot be taught using technology." The authors have argued that technology should never be used for the sake of it. However, we will continue 
to advocate that the teaching and learning and assessment and support across all subjects can be aided and enhanced by using technology appropriately.

e. "It is one of those passing fads." This is not the case. The authors began these sets of recommendations by exploring the importance and rationale behind the drive for TEL initiatives. The Higher Education landscape has changed in many ways. Government directives, changes in the student population, and the changing consensus on what constitutes effective teaching practice each provide sound incentives for this shift. For education to reach a large volume of students who otherwise may not have the opportunity to study a particular course, technology can bridge this gap. Today, social media, VLEs and online research are standards expected by students. The authors have argued that universities need to provide the space and opportunities for academics to consider the reasons why TEL is necessary to support existing teaching and learning practices. Of course, subject differences are real. Use of TEL in mathematics will be different from its use in history in some respects. However, given that TEL is used widely across most universities, it's necessary to deal with this at scale.

Incremental adoption:

1. Universities should identify academic champions for each TEL initiative and then resource and support each. A lead academic will add credibility to the initiative, both with other academics and with students. S/he will often become an exemplar of practice.

The business case for Newcastle's lecture capture initiative, ReCap, was marvellously summarised in four words by the then Degree Programme Director of the prestigious MBBS programme, Professor Phillip Bradley:

"My students love it!"

Further, by considering these people as role models, the myths above - no time, no support, not relevant to subject discipline - are effectively deflated. Done well, good practice will then permeate through the institution. Universities should consider such roles as a marker of esteem for these individuals - supporting a future case for leadership roles.

2. Universities must allow for innovation to 'bubble up' across the organisation. This appears contradictory to the discussion above about an institutional approach, but it is not. Enlightened policy and operating at scale are important, but academics must also feel encouraged to experiment with their teaching. Each university will find its own balance between supporting experimentation and mandating standards - the authors suggest that this should be debated openly across the institution. Often, innovation 
comes from collaborations between institutions. In these cases, technological solutions need to be crafted to fit the different needs of the organisations.

3. Universities must recognise that academics are coming from different starting points. Policies and training will need to address some of the practical considerations for implementing technology: Academics should be encouraged to start small with simple ways to enhance existing modules. Options might include increased collaboration between students, more self-testing and reflection opportunities, or greater interaction with relevant multimedia. A personalised approach to staff training and digital literacy is absolutely vital. TEL adoption must be tailored to real learning needs and the motivations of academic staff to have a sustainable effect that leads to transformative teaching. This needs to cover the different responsibilities that come with delivering teaching online such as facilitating, instructing, collaborating and enabling.

4. Universities must take into account students' aptitudes and attitudes. Consider and involve students, their skill set and how the use of technology can encourage and empower their learning. Move on to creating TEL initiative that are meaningful and useful for the students by highlighting the benefits of tasks which use technology and how the learning experience will be improved.

5. Universities need to offer more than just training on how to use software. TEL needs to be grounded in the pedagogical imperatives of the university. For example, the decision in Newcastle to offer lecture capture in many rooms was driven from an academic commitment to facilitate reflective learning, not by an inherent interest in the technology. Other considerations include:

a) Understanding the necessity of social presence, collaborative learning, sense of belonging and transactional learning in the design of the curriculum.

b) Designing online spaces for increased flexibility.

c) Understanding how using TEL can enrich what the tutor is able to do in the classroom. This includes designing on-campus spaces to reflect the changed pedagogies of TEL. For example, the University of Newcastle Australia is constructing its new teaching centre with spaces specifically designed as 'flipped classrooms.' (Burd, 2013).

d) Empowering students to become more self-directing, and less dependent on the tutor to provide explicit instruction.

e) Designing and supporting collaborations which are simply impossible inside the classroom. Working with peers around the world allows students to benefit from a culturally rich exchange of ideas, and discussions of diverse beliefs and practices.

\section{Summary of recommendations}

Policy Led

1. Facilitate a two-way communication

2. Change the culture of academic practice and recognition

3. Put in place a combined approach to TEL

4. Value both academic and technical support for TEL

5. Use meaningful names for TEL projects

Large scale

1. Gently move towards a consistent set of technologies

2. Address the myths of using technology in education 
Incremental adoption

1. Identify academic champions for each TEL initiative

2. Allow for innovation to 'bubble up' across the organisation

3. Recognise that academics are coming from different starting points

4. Take into account students' aptitudes and attitudes

5. Offer more than just training on how to use software

\section{Impact of this study}

This study offers the findings of a contextual analysis on the barriers and enablers to the adoption of TEL, privileging the academic's voice and lived experience. Using these findings, a set of recommendations has been designed for universities to support academics in implementing their strategy on TEL.

Individuals can use the analysis, model and recommendations to craft their own practice. Institutions can use the recommendations to move beyond adopting technology as a series of point solutions and towards a more efficient integrated approach, in support of their teaching and students' learning.

Although there is no single best practice for full adoption of TEL across a university, it is envisaged that the recommendations will equip academic leaders and curriculum designers to realise the benefits of effective adoption of TEL across subject disciplines. The effective adoption of TEL could transform universities to offer the much needed flexible learning, flexible teaching and flexible curriculum (Barnett, 2014), both to home students and students across the world. The findings will benefit University leaders (who may lack information on whether existing staff development approaches are sufficient) to explore how the barriers and motivators can be used to develop TEL in an institution. The study offers university leaders strategies to influence and inspire academics who are yet to fully engage with adopting TEL. For practicing academics, this study contributes to developing an underlying pedagogical rationale that changes the perception of TEL, allowing for adoption that is sustainable and transformative across a range of subject disciplines. Finally, for researchers, the details of the methodology used may inform future work. 


\section{References}

Aarons GA, Hurlburt M, Horwitz SM, (2011), ‘Advancing a conceptual model of evidence-based practice implementation in child welfare', Administration and Policy in Mental Health and Mental Health Services Research.

Armstrong, M. (2006), A Handbook of Human Resource Management Practice, 10th ed., Kogan, London

Babbie, E. (2010), The Practice of Social Research', $12^{\text {th }}$ edition, Wadsworth: Cengage Publishing.

Beaty, E., Cousin, G. \& Deepwell, F. (2002) Introducing e-learning via a community network: a teaching and learning strategy in action, Networked Learning Conference Proceedings, 26-28 March 2002, p. 36-40.

Barton, S, Corbitt, B, Nguyen, L and Peszynski, K (2007), 'Cultural factors behind the adoption of e-learning in turkey', in Proceedings of the 18th Australasian Conference on Information Systems, Toowoomba, Queensland, 5 - 7 December 2007.

Baxter \& Jack, (2008) 'Qualitative Case Study Methodology: Study Design and Implementation for Novice Researchers’ The Qualitative Report Volume 13(4), p.544559, Accessed 09/02/2015 from http://www.nova.edu/ssss/QR/QR13-4/baxter.pdf

Berta, W., Teare, G.F., Gilbart, E., Ginsburg, L.S., Lemieux-Charles, L., Davis, D., Rappolt, S., (2005) 'The contingencies of organizational learning in long-term care: factors that affect innovation adoption', Health Care Management Review Vol.30 (4), p.282-292.

Beetham, H., McGill, L. \& Littlejohn, A. (2009) 'Thriving in the 21st century: learning Literacies for the digital age (LliDA Project)', JISC, Accessed 12/03/15 from http://www.caledonianacademy.net/spaces/LLiDA/uploads/Main/LLiDAreportJune09.pdf

Beetham, H., \& Sharpe, R. (Eds.) (2007). Rethinking pedagogy for a digital age. London and New York: Routledge

Beetham, H. \& Sharpe, R. (2013) Rethinking Pedagogy for a Digital Age: Designing for 21st Century Learning. 2nd edn, Routledge, New York

Betts, K. S. (1998). Factors influencing faculty participation in distance education in postsecondary education in the United States: an institutional study. Doctoral, George Washington University, Washington D.C., Accessed 12/03/15 from http://proquest.umi.com/pqdweb?index $=0 \&$ did $=732907971 \&$ SrchMode $=1 \&$ sid $=1 \&$ Fmt $=$ $13 \&$ VInst $=$ PROD\&VType $=$ PQD\&RQT $=309 \& V N a m e=P Q D \& T S=1175505505 \&$ clientId $=165322$

Betts, K. S. (1998). An institutional overview: factors influencing faculty participation in distance education in postsecondary education in the United States: an institutional study. 
Online journal of distance learning administration, Vol.1(3), 13. Accessed 12/03/15 from http://www.westga.edu/ distance/ojdla/fall13/betts13.pdff

Berge, Z. L., \& Muilenburg, L. Y. (2003). Obstacles faced at various stages of capability regarding distance education in institutions of higher education: survey results. Accessed 12/11/14 from www.emoderators.com/barriers/hghred_stgs.shtml

Benz, C. and Newman, I. (1998). Qualitative-Quantitative Research Methodology: Exploring the interactive continuum, Southern Illinois University Press, Carbondale

Browne, T., Hewitt, R., Jenkins, M., Voce, J., Walker, R. \& Yip, H. (2010). '2010 survey of Technology Enhanced Learning For Higher Education in the UK’. A JISC/UCISA funded survey.

Burd, L. (2013) 2013 New Professors Talk with Liz Burd, University of Newcastle, Australia, accessed on 8/5/2015 from https://www.youtube.com/watch?v=WckMZiEBe7o

Burke \& Litwin, (1992) 'A Causal Model of Organisation Performance and Change', Journal of Management, Vol 18, No 3, p.523-545.

Burnes, B. (2004). Kurt Lewin and the planned approach to change: A re-appraisal. Journal of Management Studies, Vol.41(6), p.977-1002

Bryman, A. (2004). Social research methods (2nd ed.). Melbourne: Oxford University Press.

Calvert, J. (2005) Distance education at the crossroad, Distance Education, Vol.26(2), p.227-238.

Chen, B. (2009), 'Barriers to adoption of technology-mediated distance education in higher-education institutions’, The Quarterly Review of Distance Learning, Vol.10(4), p.333-338.

Cohen, L., Manion, L., \& Morrison, K., (2007) Research Methods in Education, $6^{\text {th }}$ Edition, London: Routledge-Falmer

Collins, J. (2001). Good to great: Why some companies make the leap and others don't. New York: HarperCollins.

Collis, B. \& van der Wende, M. (2002) Models of technology and change in higher education, report, University of Twente, Accessed 12/11/14 from http://www.utwente.nl/cheps/documenten/ictrapport.pdf

Cummings, Rick, Phillips, Rob, Tilbrook, Tilda and Lowe, Kate (2005) Middle-out approaches to the reform of university teaching and learning: champions striding between the 'top-down' and 'bottom-up' approaches. The International Review of Research on 
Open and Distance Learning Vol 6 No 1. Accessed 12/11/14 from http://www.irrodl.org/index.php/irrodl/article/viewArticle/224/307

Conole, G. (2002) The evolving landscape of learning technology research. ALT-J 10(3), 4-18

Damanpour and Schneider (2006), 'Phases of the Adoption of Innovation in Organizations: Effects of Environment, Organization and Top Managers’, British Journal of Management, Volume 17, Issue 3, Accessed 12/11/14 from http://onlinelibrary.wiley.com/doi/10.1111/j.1467-8551.2006.00498.x/full

Dawson, P. (1994). Organizational change: A processual approach. London: Paul Chapman Publishing

Dooley, K., \& Murphrey, T. (2000). How the Perspectives of Administrators, Faculty, and Support Units Impact the Rate of Distance Education Adoption. Online journal of distance learning administration Vol.3(4) http://www.westga.edu/ distance/ojdla/winter34/dooley34.pdf

Douglas, J.A. (2005). All globalization is local: Countervailing forces and the influence on higher education markets. Paper CSHE. Berkely, eScholarship Repository, University of California. Accessed 12/11/14 from http://repositories.cdlib.org/cshe/CSHE-1-05/

Dickson, T. (2004, February) Things to come, conference opening address at When worlds collide, JISC infoNet Conference, York (York, JISC infoNet and HEFCE).

De Freitas, S. \& Oliver, M. (2005) Does e-learning policy drive change in higher education? A case study relating models of organizational change to e-learning implementation, Journal of Higher Education Policy and Management, Vol.27, 81.

European ODL Liaison Committee. (2004). Distance learning and elearning in European policy and practice: The vision and the reality. Accessed 01/02/15 from http://www.odlliaison.org/pages.php?PN=policypaperr

Elrod, P.D. II \& Tippett, D.D. (2002), The "Death Valley of change, Journal of Organizational Change Management, Vol.15(3), p.273-91.

Eisenhardt KM., (1989) Building theories from case study research, Academy of Management Review, 14(4)

Frost, S., \& Chopp, R. (2004), 'The university as global city: A new way of seeing today’s academy’, Change, 36(2), p.44-51.

Farrell, L. (2001) 'Negotiating Knowledge in the Knowledge Economy: workplace educators and the politics of codification', Studies in Continuing Education, Vol.23 (2), p.201-214. 
Friesen, N., Gourlay, L. \& Oliver, M. (2014) 'Editorial: scholarship and literacies in a digital age’, Research in Learning Technology, vol. 21

Feldstein, A. C., \& Glasgow, R. E. (2008), 'A practical, robust implementation and sustainability model (PRISM) for integrating research findings into practice', Joint Commission Journal on Quality and Patient Safety, 34(4), p228-243.

Gartner, 'Bimodal IT’ Accessed 01/02/15 http://www.gartner.com/it-glossary/bimodal (2013)

Gallivan, M.J., (2001). Organizational adoption and assimilation of complex technological innovations: Development and application of a new framework. The database for Advances in Information Systems - Summer 2001, Vol. 32, No. 3, p.51-85.

Graham, R. J. (2006). Factors influencing faculty decisions to incorporate blended and totally online instruction at a private urban university. Doctor of Education, St. John's University, N.Y.

Gourlay, L., Hamilton, M. \& Lea, M. (2014) 'Textual practices in the new media digital landscape: messing with digital literacies’, Research in Learning Technology, vol. 21, p.21438.

Gilly, S. (2005) 'Flying not flapping: a strategic framework for e-learning and pedagogical innovation in higher education institutions', ALT-J, 13: 3, $201-218$, Accessed 01/02/15 from http://dx.doi.org/10.1080/09687760500376439

Garrison, D \& Vaughan, N. (2008), ‘Blended learning in higher education’, San Francisco: Jossey-Bass.

Garrison, D. R., \& Anderson, T. (2003). E-Learning in the 21st century: A framework for research and practice. London: Routledge/Falmer.

Garrison, D. R., \& Kanuka, H. (2004). Blended learning: Uncovering its transformative potential in higher education. The Internet and Higher Education, Vol.7(2), p.95-105.

Garrett, R. \& Jokivirta, L. (2004) Online learning in commonwealth universities: selected data from the 2004 Observatory Survey, Part. 1, Report no. 20 (London, The Observatory on Borderless Higher Education).

Glasgow, R. E., Lichtenstein, E., \& Marcus, A. C. (2003). Why don't we see more translation of health promotion research to practice? Rethinking the efficacy-toeffectiveness transition. American Journal of Public Health, 93(8), p.1261-1267.

Graham, I.; Logan, J. (2004). Innovation in Knowledge Transfer and Continuity of Care. Canadian Journal of Nursing Research, Vol.36, 2, p.89-103

Guba, E.G., \& Lincoln, Y.S. (1985). Naturalistic inquiry. Beverly Hills, CA, Sage. 
Guba, E.G. and Lincoln, Y.S. (1994), “Competing paradigms in qualitative research”, in Denzin, N.K. and Lincoln, Y.S. (Eds), Handbook of Qualitative Research , Sage, Thousand Oaks, CA, p.105-117.

Goodyear, P. (2005) Educational design and networked learning: patterns, pattern languages and design practice, Australasian Journal of Educational Technology, Vol.21(1), p.82-101.

Holley, D. \& Oliver, M. (2001). 'Pedagogy and new power relationships'. International Journal of Management Education, Vol.1 (1), p.11-21.

HEFCE (2005) HEFCE Strategy for E-Learning 2005/12. Bristol, UK, Higher Education Funding Council for England (HEFCE), Accessed 01/02/15 from http://www.hefce.ac.uk/pubs/hefce/2005/05_12/

Hammond, Nick (2003) Learning technology in higher education in the UK: Trends, drivers and strategies. In M. Van der Wende and M. van der Ven (eds), The use of ICT in Higher Education: A mirror of Europe. Lemma Publishers: Utrecht, p.109-122.

Hutchings, P., Huber, M. T., \& Ciccone, A. (2011). The scholarship of teaching and learning reconsidered: Institutional integration and impact. San Francisco: Jossey-Bass.

Holmes, B. and Gardner, J. (2006), E-learning: Concepts and Practice, Sage Publishing, Thousand Oaks, CA.

Jacobsen, D. M. (2000) 'Examining Technology Adoption Patterns by Faculty in Higher Education' Proceedings of ACEC2000: Learning Technologies, Teaching and the Future of Schools, July 6-9, Melbourne, Australia

Johnson, B. and Christensen, L. (2004). Educational Research: Quantitative, Qualitative, and Mixed Approaches, Research Edition, Second Edition Pearson Education Inc., Boston.

Kirriemuir, J. (2008). A spring 2008 'snapshot' of UK Higher and Further Education developments in Second Life. Eduserv Virtual World Watch. Accessed 01/02/15 from http://www.scribd.com/doc/7063700/A-Spring-2008-snapshot-of-UK-Higher-andFurther-Education-Developments-in-Second-Life

Kirriemuir, J. (2010) 'Virtual World Activity in UK Universities and Colleges: What now?’ Accessed 01/02/15 from http://virtualworldwatch.net/vww/wpcontent/uploads/2011/09/Snapshot-9.pdf

Kelton, A.J. (2007). Second Life: Reaching into the virtual world for real-world learning. Boulder, CO: EDUCAUSE Center for Applied Research. Accessed 01/02/15 from http://www.educause.edu/ir/library/pdf/ERB0717.pdf 
Kelton, A.J. (2008). Virtual worlds? “Outlook good”. EDUCAUSE Review, 43(5), 15-22. Accessed 01/02/15 from http://www.educause.edu/ir/library/pdf/ERM0850.pdf

Kanter, R. M., Stein, B. A. and Jick, T. D. (1992). The Challenge of Organizational Change. New York: Free Press.

Kotter, J. (2007) Leading Change: Why transformation efforts fail', Harward Business Review, p.1-10

Kotter, Change Management blog, Accessed 01/02/15 from http://www.changemanagement-blog.com/2009/07/change-model-3-john-kotters-8-steps-of.html

Kotter, J.P. (1996), Leading Change, Harvard Business School Press, Boston, MA.

Kotter, J.P. and Cohen, D.S. (2002), The Heart of Change: Real Life Stories of How People Change Their Organizations, Harvard Business School Press, Boston, MA.

Lane, C. A., \& Lyle, H. F. (2011). Obstacles and supports related to the use of educational technologies: The role of technological expertise, gender, and age. Journal of Computing in Higher Education, Vol.23(1), 38-59.

Lewin, K. (1951), Field Theory in Social Science, Harper and Row, New York, NY

Larson, A. (2005). Lifelong learning at the international agenda - and its implementation in a Danish context. In S. Kiefer \& T. Peterseil (Eds.), Analysis of educational policies in a comparative perspective, p123-140, Linz: Trauner Verlag.

Larson, A. (2006). Participation and non-participation in adult education and training. In S. Ehlers (Ed.), Milestones - towards lifelong learning systems (pp. 47-61). Copenhagen: Danish University of Education Press.

Lasswell, H (1948), ‘Power and Personality’, NY

Laurillard, D. (2004) The next level in e-learning, Proceedings of Online Educa Berlin, (Berlin, ICWE) p.452-455.

Laurillard, D. (2007), 'The pedagogical challenges to collaborative technologies', International Journal of Computer-Supported Collaborative Learning, Vol.4 (1) p.5-20, Accessed 01/02/15 from http://eprints.ioe.ac.uk/626/1/laurillard2009Thepedagogical.pdf

Lewin, K. (1947). Frontiers in group dynamics. In D. Cartwright (Ed.), Field Theory in Social Science. London: Social Science Paperbacks.

Lewin, K. (1951). Field theory in social science: Selected theoretical papers (D. Cartwright, Ed.). New York: Harper \& Brothers. 
Lincoln, Y.S. (2001). The fourth generation view of evaluation: The future for evaluation in a new millennium. Keynote address at the 2001 Arizona Evaluation Network's Spring Conference. Accessed 01/02/15 from http://aspin.asu.edu/azenet/fall01.html\#yvonnaa

Lincoln, Y.S. and Guba, E.G. (2000), 'Paradigmatic controversies, contradictions and emerging confluences', in Denzin, N.K. and Lincoln, Y.S. (Eds), Handbook of

Qualitative Research , 2nd ed., Sage Publications Inc., Thousand Oaks, CA, p.163-188

McKinsey (2012) Quarterly, Accessed 01/02/15 from

http://www.mckinseyquarterly.com/Organization/Change_Management/Economic_Condi tions_Sn

Mays, N. and Pope, C. (2000). Qualitative research in health care: Assessing quality in qualitative research, British Medical Journal 320(7226), p.50-52.

Marshek. R 1993, Lewin meets confucious, The Journal of applied behavioural Science, NTL institute, vol. 29 no. 4

Mendel, P., C. L. Damberg, M. E. S. Sorbero, D. M. Varda, and D. O. Farley (2008) 'The Growth of Partnerships to Support Patient Safety Practice Adoption', Health Services Research, Accessed 01/03/15 from http://www.ncbi.nlm.nih.gov/pmc/articles/PMC2677037/

McEwen, M., \& Wills, E.M. (2007). Theoretical Basis for Nursing $2^{\text {nd }}$ Edition. New York, NY: Lippincott Williams \& Wilkins.

Mitchell S., Fisher C., Hastings C., Silverman L. \& Wallen G. (2010) A thematic analysis of theoretical models for translational science in nursing: mapping the field. Nursing Outlook 58, p.287-300.

Morris, David (2008) Economies of scale and scope in e-learning. Studies in Higher Education. Vol 33 No 3 pp331-343

Mies, M., \& Vandana, S. (1993). Ecofeminism. Melbourne: Spinifex.

Maguire, L. (2005). Literature review- faculty perception in online distance education: barriers and motivators. Online journal of distance education, Vol.8(1). Accessed 01/03/15 from http://www.westga.edu/ distance/ojdla/spring81/maguire81.htm

Nardi, and O’Day (1999). Information Ecologies. Using Technology with Heart. Cambridge, Massachusetts. MIT press.

Netteland G., Wasson B. and Morch A.I., 2007, E-learning in a large organization. A study of the critical role of information sharing, Journal of Workspace Learning, vol.19, no.6, pp.392-411

Nuendorf, K. (2002), ‘The Content Analysis Guidebooj’, Thousands Oaks, CA: Sage 
Oliver, M. \& Dempster, J. (2003) 'Embedding e-learning practices, in: R. Blackwell \& P. Blackmore (Eds) Towards strategic staff development in higher education’ (Buckingham, SRHE and Open University Press), 142-153.

Onwuegbuzie, A. and Teddlie, C. (2003). A framework for analyzing data in mixed methods research. Handbook of Mixed Methods in Social and Behavioral Research. Tashakkori A and Teddlie, C., Ed., Sage, Thousands Oaks.

OECD (2005) E-learning in tertiary education: where do we stand? Paris: OECD/CERI

Oldenburg B, Glanz K. Diffusion of innovations. In: Glanz K, Rimer BK, Viswanath K, eds. Health Behavior and Health Education: Theory, Research and Practice, 4th ed. San Francisco, CA: Jossey-Bass; 2008m, p.313-333

Parker, A. (2003). Motivation and incentives for distance faculty. Online Journal of Distance Learning Administration, Vol.6(3), 1-6, Accessed 01/03/15 from http://www.westga.edu/ distance/ojdla/fall63/parker63.htm

Picciano, A \& Dziuban, C (2007), Blended learning: Research perspectives. Needham, MA: Sloan Consortium.

Pfeffer, J., \& Salancik, G.R. (1978). The external control of organisations; A resource dependency perspective. New York and San Fransisco: Harper \& Row Publishers

Ritchie, J. and J. Lewis (2003), Qualitative research practice: a guide for social science students and researchers, London Sage.

Rogers, E. (2003). Diffusion of innovations (5th ed.). N.Y.: Free Press.

Rosenberg, M.J.E-l.e. (2001), earning: Strategies for Delivering Knowledge in the Digital Age, McGraw-Hill Professional, Boston, MA.

Saunders, M., Lewis, P. and Thornhill, A. (2000) Research methods for business students. 2nd edition. Harlow: Pearson Education.

Servage, L. (2005), 'Strategizing for workplace e-learning: some critical considerations', Journal of Workplace Learning, Vol. 17 Nos 5/6, p.304-17

Seely-Brown, J. \& Duguid, P. (1991) Organizational learning and communities of practice: toward a unified view of working, learning, and innovation, Organization Science, 2(1), p.40-57.

Solomons, N., \& Spross, J. (2011). Evidence-based practice barriers and facilitators from a continuous quality improvement perspective: an integrative review. Journal Of Nursing Management, 19(1), p.109-120. 
Smith, P. (2004). Curricular transformation: Why we need it and how to support it. Change, 36(1), p.28-35.

Salmon, G. (2005) Flying Not Flapping: A Strategic Framework for E-Learning and Pedagogical Innovation in Higher Education Institutions. ALT-J, 13:3, p.201-218.

Schiffman, Stephen, Vignare, Karen \& Geith, Christine (2007) Why do higher education institutions pursue online education? Journal of Asynchronous Learning Networks Vol 11 No 2, pp61-71 Accessed 01/03/15 from http://www.sloan c.org/publications/jaln/v11n2/pdf/v11n2_schiffman.pdf

Sharpe, R. \& Beetham, H. (2010) Understanding students' uses of technology for learning: towards creative appropriation, in R. Sharpe, H. Beetham and S. de Freitas (Eds.) Rethinking learning for the digital age: how learners shape their experiences, p.85 - 99. RoutledgeFalmer, London and New York.

Stiles, M. (2004) Is an eLearning strategy enough?, Educational Developments, 5(1), p.13-15.

Simmons, D. E. (2002). The forum report: E-learning adoption rates and barriers. In A. Rossett (Ed.). The ASTD E-learning Handbook: Best practices, strategies and case studies for an emerging field, (pp. 19-23). New York: McGraw Hill.

Shaw, P. (2002) Changing Conversations in Organizations: A Complexity Approach to Change. London: Routledge.

Tatnall, A. and Davey, B. (2003). "ICT and Training: A Proposal for an Ecological Model of Innovation”. Education Technology and Society. Vol. 6, No. 1, p.14-17.

Trowler, P. (1998) Academics Responding to Change New Higher Education Frameworks and Academic Cultures, Buckingham, Society for Research into Higher Education Open University Press

Thanaraj \& Williams, (2014) 'Embedding Technology Enhanced Learning at Universities: A collaboration between University of Cumbria and Newcastle University; Journal of Learning Development in Higher Education, Special Edition on Digital Technology

UCISA report, 2010 Survey of Technology Enhanced Learning for higher education in the UK, Accessed 01/03/15 from http://www.ucisa.ac.uk/groups/ssg/ /media/groups/ssg/surveys/TEL\%20survey\%202010 _FINAL.ashx

UCISA report, 2012 Survey of Technology Enhanced Learning: case studies, Accessed 01/03/15 from http://www.ucisa.ac.uk/ /media/groups/ssg/surveys/TEL\%20Survey\%202012\%20Case\% 20studies_FINAL 
U.S. Department of Education, Office of Planning, Evaluation, and Policy Development, Evaluation of Evidence-Based Practices in Online Learning: A Meta-Analysis and Review of Online Learning Studies, Washington, D.C., 2010, Accessed 01/03/15 from http://www2.ed.gov/about/offices/list/opepd/ppss/reports.html

Vankatesh, V., \& Bala, H. (2008). Technology acceptance model 3 and a research agenda on interventions. Decision sciences, 39(2), 42

Warburton, S. \& Perez-Garcia, M. (2009). 3D design and collaboration in massively multi-user virtual environments. In D.Russel (Ed.), Cases on collaboration in virtual learning environments: processes and interactions. Hershey, PA: IGI Global.

Yin, R. K.: Case Study Research, Design and Methods. Sage publications, Newbury Park, CA. (1994).

Welsh, E., Wanberg, C., Brown, K. and Simmering, M. (2003), 'E-learning: emerging uses, empirical results and future directions', International Journal of Training and Development, Vol. 7 No. 4, p. 245-258. 